\title{
The awareness of indonesian students toward autonomous learning
}

\author{
Dony Marzuki \\ Politeknik Negeri Padang Jurusan Bahasa Inggris \\ bugepnp@yahoo.co.id
}

\begin{abstract}
This writing reports the finding of a quantitative study which sought to find out the awareness of Indonesian students toward autonomous learning. This was a survey to twelve Indonesian students at their first year at Flinders University. The survey used adapted and revised questionnaire about autonomous learning which was answered on-line by respondents. Survey Gizmo was utilized for this purpose. Analysis of the data by using SPSS ver. 15.0 showed that most Indonesian students from various different background such as gender, age, hometown, occupation, and field of study have already aware of autonomous learning at almost the same level. Little different of autonomous learning level appeared on the comparison to hometowns of respondents. Respondents from Java had higher level of autonomous learning than those from outside Java. Since this study involved small proportion of Indonesian students in a specific place of Australia, similar study needs to be conducted with wider scope to find out the real condition.
\end{abstract}

\section{CHAPTER I}

\section{Introduction.}

T Becoming autonomous in learning is one of the requirements needed by students at higher level of education, especially in postgraduate level. As mentioned by Railton and Watson (2005) in their journal article that learning to become autonomous learners is the most significant factor for university students, no matter what the students discipline is.

In postgraduate level, the demand to be autonomous learner is higher and educators in this level should focus their practice in this matter (Chan, 2001). Here, students are required to be able to manage their study and to achieve the goals of the study base on their own ways. They must be fully involved in all learning process to ensure academic success. Research findings have made suggestion about how to be an autonomous learner in a higher degree education. Van Lier (1996) mentioned that learners must be fully responsible for their learning and for deciding the choice to learn in order to gain success in their learning. According to Little (1995), there must be clear objectives, good initiatives and ability to measure or evaluate the process and result of learning in an autonomous context. Supporting opinion can be seen from Chan (2001) who pointed out the autonomous learner as:

"being actively involved at all levels of learning, from goal-setting, defining content and working out mechanisms for assessing achievement and progress and points out that the locus of control for decision-making shifts from teacher to student" (p. 285).

The conclusion for the above statement can be found in Dickenson (1993, p.330), who describes autonomous learners as learners who exactly know the purpose of study they are involving with, should be able to define objectives of the study, and can choose and apply suitable strategies as 
well as to combine or change those strategies in order to get the best result. These abilities are required by an autonomous learner.

It seems difficult to be an autonomous learner if students do not have a good background about this concept. It needs students' awareness toward their status as an adult student who must be autonomous in learning. Every student has a different perception about this autonomous concept. Some of them know that they must be autonomous in learning but never make any attempts on it, while others may not realize it at all. Even though the existence of autonomous learners among Indonesian students studying in foreign western-background country like Australia can be noticed, the real condition needs to be revealed since there are many factors influence the autonomous behaviour.

Indonesian students are mostly educated in traditional education background in the first, secondary, and even the tertiary level. The students are trained to study according to anything designed and directed by the teacher and this happens in most Asian countries, accordingly students are categorised as reactive students (Littlewood, 1999). This educational background may be a weakness for students who decide or get an opportunity to continue their study in the western educational system in Australia which is known as proactive autonomous learning system, which can be substantially different from their experiences in their own culture. Students from areas in Indonesia that are considered modern in the delivery of education such as provinces in Java, may be more likely to adjust to an autonomous learning style, in comparison to those from outside Java. This factor may also influences students in understanding and practicing the autonomous concept in learning.

This proposed study sought to find out the level of awareness of Indonesian students about autonomous learning while studying in Flinders University. It also revealed the questions about activities conducted by the students as autonomous learners, and found out factors influencing their awareness toward the autonomous learning concept.

With the recent increase of Indonesian students studying at the postgraduate level in western background countries, the issue of autonomous learning is important since these students have to deal with this issue when conducting study. These students must be aware about this before they start studying or even before they arrive in the university. Accordingly, this proposed research will be of importance in providing better understanding for educational institutions in Indonesia to prepare their graduates to study abroad. This research may also contribute to the understanding of targeted western style universities in Australia about the condition of Indonesian students as their future students.

However, since this study was only conducted to a small group of Indonesian students concentrated at Flinders university, the result may be not enough to prove the real condition about the awareness of Indonesian students toward autonomous learning.

\section{CHAPTER II}

\section{Literature Review}

Regarding the importance of autonomous learning to be possessed by university students, many researchers have been conducted on this issue. Studies conducted by Ho \& Croocall (1995), Chan (2001), Railton \& Watson (2005), and Conttia (2007) have proved the significance of autonomous learning for students in order to be successful in their learning. Similar study needs to be applied to Indonesian students who continue their education at foreign universities like Flinders. These students must be aware of the concept of autonomous learning which has been an identity of the university.

Definition of Autonomous learning

The general idea about autonomous learning is that learners must be able to plan, conduct, and evaluate their learning and also independently overcome any problems related to it. Learners must also be able to determine priorities in the learning process and commit with it.

Autonomous learning most often relate to self-directed learning, where by in the learning process the learner must rely on their own ability. As defined by Ponton (1999), a person who is independent in learning activities and represents the characteristic associated with self-directedness is regarded as autonomous learner. It means that learners have their own freedom to determine and 
self regulate their learning process in order to achieve the goal of study. This idea was supported by Benson, (2001) and Holec (1988) that an autonomous learner must be able to take control of his own learning and has the ability to selfdirected his learning. The key point in autonomous learning is actually in the success of achieving the learning objective and facilitating further opportunities for the learner to learn in their preferred learning styles. It is hoped then that learners will focus on effectively carrying out their learning goals with their active engagement in planning and practicing learning agendas and strategies (Little, 2003). In addition, Railton and Watson (2005) stated about the important of autonomous learning in studying in higher degree setting where learners are hoped to be independent, self directed, pro-active, creative, anticipative, and become absolutely responsible for their own educational lives.

\section{The practice of autonomous learning}

The Western educational system is different from the Asian system in many aspects including the concepts of autonomy in teaching and learning practice. In Western countries, students are familiar with autonomous learning due to their exposure to it throughout their education. Most of the teaching and learning practices use student-centred approach that gives more control to the students. On the other hand, in most Asian countries the education system has adopted the teacher-centred approach that positions the teacher as a sole authority and source of knowledge (Lin, 2008). This approach may make learners become dependent in their study and may present them with difficulties if they receive less support from the teacher. This difference of approach affects learners understanding about learning when they enter higher degree education, especially if they decide to continue study in a country with a different system of education. Usually, these students tend to be uncomfortable and are less involved in the learning process (Ho \& Crookall, 1995). This often makes it difficult for the student to adapt to a different system and can influence their achievement.

Other concept of autonomous learning can be seen in Pennycook (1997) that suggest autonomy is only appropriate for the West since it has become part of its ideological drive towards libertarian, democratic individualism in the broader sense, and its promotion of learner-centred, process-oriented teaching. This concept from Pennycook gives a limited interpretation of autonomy, which aims at promoting individual self-development through developing appropriate strategies that seems applicable for any one in various contexts. However, in the application, several studies conducted by Benson (1997), Hasanah (1997), Lewis (1997), and Pennycook (1997), proved that most western countries have applied this autonomous concept in their educational setting while very few, if any, Asian countries, including Indonesia, adopt the concept for their educational setting.

These finding should be addressed by the Indonesian government who regularly sends their students to study in Australia and places them in western educational systems with the autonomous learning approach. This research investigates the awareness of Indonesian students toward autonomous learning and hopes to provide more understanding about the condition of education in Indonesia which is reflected by some Indonesian students studying in Flinders University at this time.

\section{Indonesian Educational Context}

Indonesian educational system adopts the Dutch system in many aspects, especially for the length of study time and types of institutions (Ajisukmo, Clara, and Vermunt, 1999). Indonesia uses the term of nine years basic education from elementary to junior high school, which is compulsory for all children on the age range, three years senior high school, three to five years undergraduate that divided into three years study for vocational diploma or non bachelor (D3) and four to five years bachelor (S1), and the post graduate degree that consists of master degree which usually takes two year which then continued by doctoral degree for another three to four years of study. This context has a slight difference with the western system in term of undergraduate education, where it takes longer for Indonesian students to finish their undergraduate level. 
In most levels, except in the post graduate level, method used in teaching and learning process is the teacher-centred classroom method. This the method in where teacher become the central figure in the educational system. The teacher is seen as the ultimate source of knowledge and students are usually waiting for the teacher to pour the knowledge into them and to give instruction about what to do and how to do it (Lewis, 1997). The teacher is also seen as source of moral value, that all of the teacher's wishes and rules must be followed without question. This approach has lasted ever since Indonesia gained freedom in 1945, and it forms part of the character of Indonesian students. Therefore, Indonesian students tend to be passive in learning, dependent and develop less academic skills. Hasanah (1997) in her research report, explained that "the Indonesian system was judged to provide all information for students and to use one-way communication, consequently producing students who did not question any material, did not develop their own ideas and lacked critical thinking skills" (p. 4). This is the characteristic that seems to be brought by some Indonesian postgraduate students studying in Australia in recent times.

However, the Indonesian government has been trying to improve this condition for some time (Karsidi, 2005; Fagih, 2007; and Yus, 2009), but is limited in many aspects, especially in funding. The improvements are generally made in major urban areas or big cities like Jakarta and others centralized in Java Island. Education in these cities has improved significantly in term of facilities and overall educational system. Some universities in Jakarta, Bandung, Jogjakarta and Surabaya are well known internationally for their research and academic achievement. Therefore, the graduate students from these areas probably developed a better awareness toward autonomous learning.

Since the improvement in the educational system seems to be centralized in the Java area, many provinces outside Java such as in Sumatera, Kalimantan and others in Eastern territory only experience little improvement. Consequently, the condition of the graduate students outside of Java may be less autonomous in learning (Lewis, 1997) and may have more difficulty in learning in western contexts compare to graduates from within Java.
What Influence autonomous learning in Indonesia?

There are many factors influence the practice of autonomous learning in Indonesia. The first major factor is the centralization of educational development in the Java area. This condition has improved educational level of many schools and universities spread out in all over Java Island from Jakarta to Surabaya. Even, some of the universities have been world-wide known and have gained the standard of education applied by most western universities. This condition will definitely improve students' capability and knowledge that also enable them to adapt better with western system, including autonomous learning concept, if they decide to continue study to western countries' universities.

The second factor, which can be assumed to be triggered by the first factor, is the migration of students from outside Java to many famous schools and universities within Java. Most high achieving students, especially upon finishing their secondary education, decide to study in Java because they think that their level can only be matched by the standard of education offered by Indonesian universities in Java such as University of Indonesia in Jakarta, Bandung Institute of Technology in Bandung and Gajah Mada University in Jogjakarta. This situation forces the outside-Java universities to receive and educate "lower level students" since the more academically-mind students migrate to Java.

The third factor, which follows on from the second factor, is that many schools, especially, universities outside Java are faced with the "lower level students". These universities with less support from government (some are the cause of district autonomy that affect education) have to struggle more than universities in Java. Most of these universities may be considered as having more burdens because they must dealt with different group of students, comparing to those in Java, with all the limitation they have. As a result, it is more difficult for the universities outside Java to produce good graduates. This will certainly reflects the condition of the graduate students to be less autonomous in learning (Lewis, 1997) and will have more difficulties in learning in western context compare to graduates from Java. 


\section{CHAPTER III}

\section{Participants}

There were twenty students from postgraduate level of Flinders University had been asked to participate in this study. They were convenience sample in this survey. They answered the designed questionnaire on-line by utilizing Survey Gizmo. From the twenty students, there were only twelve of them responded well and finished the questionnaire. Others reported that the link to Survey Gizmo provided through their email addresses were not working. Gender distribution among participants is fair enough that six females and six males were in. Eight of them were above thirty years of age while the other four were under thirty. Educational backgrounds of seven respondents were in area outside of Java and five other were from Java. Occupation distribution was unfairly collected as nine of respondents were PNS or government employees while only three of them were non PNS. The same unfair distribution happened to respondents' fields of study where eleven were in social science but only one in physical science.

\section{Questionnaire}

The questionnaire was adapted and revised from three studies focused on autonomous learning in language study. The studies were conducted by Chan (2001), Murray (2006), and Conttia (2007). More specifically, the demographic questionnaire with close-ended questions was used to investigate academic, social, personal and cultural experience of twenty postgraduates Indonesian students, as sample of convenience. Relevant statements in questionnaire to be completed by respondents such as "My previous university had functioned well in teaching and learning process" and "I try new ways of study and practice" were to investigate the autonomy of respondents before and while they started their study at Flinders. The questionnaire was designed in liker-type scale ranging from ' 1 ' $=$ "strongly disagree" to ' 5 ' = "strongly agree", and was completed on line by utilising survey gizmo.

The questionnaire was classified into four parts. The first part, as background question, was the questions dealing with respondents personal data such as gender, age, hometown, occupation and current field of study. The second part was categorized as respondents' past experience (PE) with questions ranging from condition of their previous university to their activities and results as students in that university. The third part of the questionnaire investigated respondents' current activities (CA) as first year students at Flinders University. The fourth part was directed to collect data about respondents' belief (B) as students.

Data Analysis

Respondents' answers on questionnaire were collected and analyzed to find out tendency toward autonomy. SPSS version 15.0, with the descriptive analysis and inferential statistic, was used to find out reliability of the questionnaires, mean, median and mode of data, and by using $\mathrm{t}$ test the correlation among variables such as different degree of autonomy between gender, between two categories of age, hometown, occupation, and current field of study were also revealed.

\section{Findings}

All groups of questionnaire, despite the first group, were assessed for the reliabilities. The total Cronbach's alpha value of all forty statements in the questionnaire was .83 . When it was divided into each group, the value was varied. The Cronbach's alpha value of second part which dealt with past experience (PE) was .74. The third part or statement about current activities (CA) had .87 while the fourth part appeared to be less reliable with Cronbach's alpha .49. The low reliability of the questionnaire could be caused by the difficulty to understand the statements as most of respondent were not native English as the language used in the questionnaire, number of respondents which were only twelve, and the questionnaire which was specially designed to measure degree of student's autonomy in second language field.

The independent sample t-test was applied to reveal the autonomous learning of respondents judging from several determinants such as gender, age, hometown, occupation, and field of study. As shown on table 1 , there were no significant different on the degree of autonomy between male and female. Both groups, who shared equal number of respondents, showed the same degree of autonomy in their past experience, current 
activities, and belief, as also proved by their insignificant difference of mean.

Table 1. t-test of each group's past experience based on Gender

Independent Samples Test

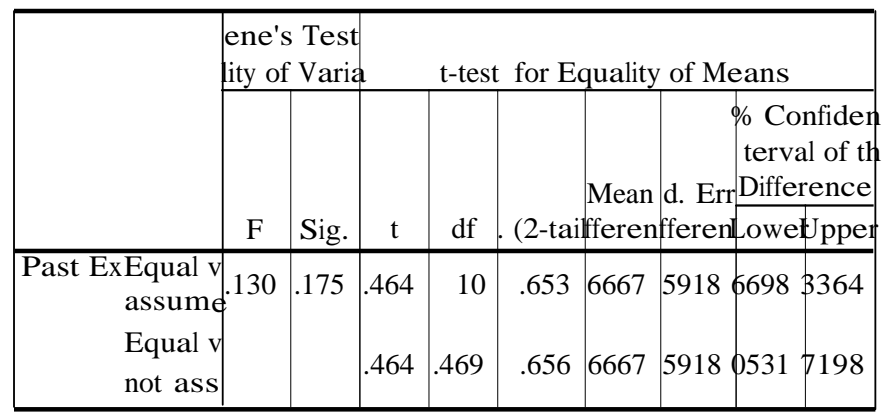

Similar result appeared on t-test applied to current activities and belief of male and female respondents. Both groups were at almost the same level of autonomy with insignificant different on their t-test result as can be seen on table 2 and 3 below.

Table 2. t-test of each group's current activities based on Gender

Independent Samples Test

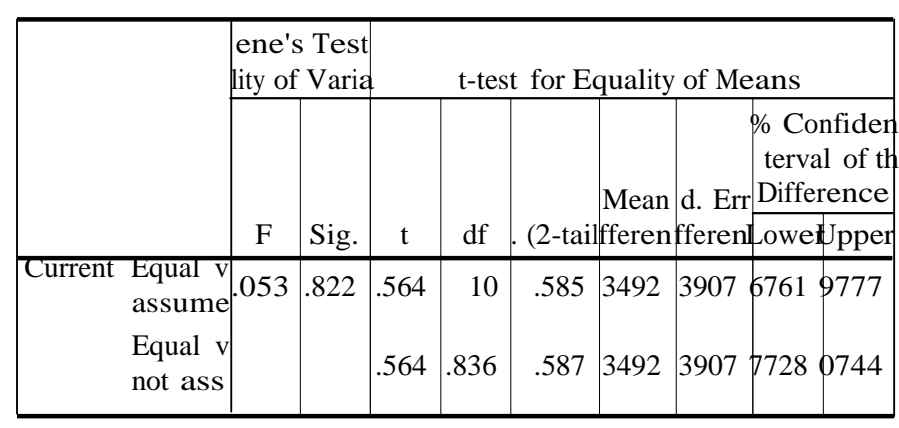

Table 3. t-test of each group's belief based on Gender

Independent Samples Test

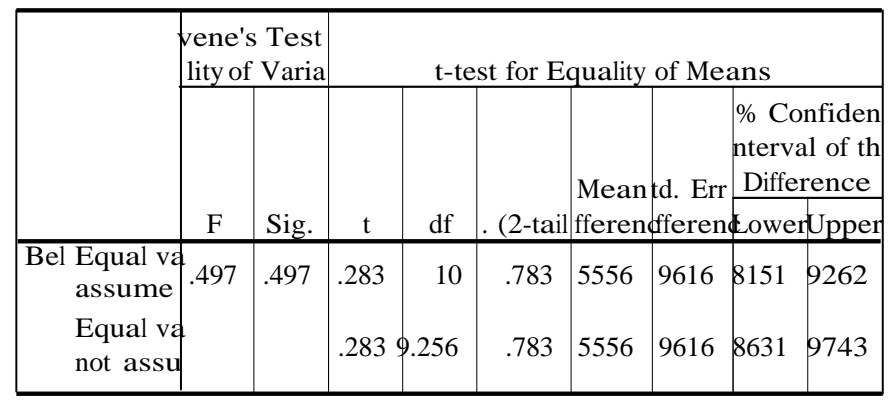

The t-test result of age showed nearly the same as in gender. There were no significant different between those variables' divisions. Respondents of under thirty years old had slight lower mean compared to those of over thirty years old when dealing with degree of autonomy in their past experience, current activities and belief (see figures B1, B2 and B3 on appendix).

A little different result appeared on t-test of hometown, either on the past experience, current activities and belief. Respondents from Java had higher mean than those from outside Java on the three groups of variables (see figures $\mathrm{C} 1, \mathrm{C} 2$ and C3 on appendix).

The t-test of last determinant, current field of study, were not available because there was unfair distribution of respondents. Respondents with social science background were eleven students while there was only one of them from physical science so the data could not be compared.

\section{CHAPTER IV}

\section{Discussion}

The awareness toward autonomous learning of students can be highlighted through the appearance of some characteristics on their activities such as their ability to set learning objectives, the ability to select, utilize and monitor learning strategies, and the ability to self-access (Dickinson, 1993. P.330). The tool used to highlight the characteristics was the questionnaire. Students' Awareness Toward Autonomous Learning

Based on the data analysis, most participants had shown significant degree of autonomy. The highest degree of autonomy was found in their belief, mean 3.8, especially when they were asked to answer the statement "I believe my success in learning depend on me". This statement had 4.4 value and became the highest mean among other statement in belief. Degree of autonomy was also found in students' current activities with 3.7. The lowest answer was on statement "I review my progress with my partners / teachers" with 2.8 , and the highest answer was on statement "I use the internet and information technology" with 4.4 mean. Although the result in past experience was lower than two other groups, mean 2.8, it still showed that respondents had already aware of autonomous learning. The low result was probably caused by condition of their previous university and all the facilities including teachers' ability. It was proved by statement "My lecturers ever asked students to decide their 
preferred class activity" with only 1.9 value. The finding surely showed that the respondents had already aware about autonomous learning, and most of them had applied it in their study.

\section{Activities Perfomed as Autonomous Learner}

\section{Self Access}

The characteristics of autonomous learners as defined by Dickinson (1993) were also found in respondents, especially in their current activities as students at Flinders University. Statements "I use the internet and information technology" and "I maximize the use of library and any other facilities for studying", as the first and second highest value, proved that respondents had the ability of self access in their study. The same condition occurred to statement "I use many resources like references, books, and journals" that also had second highest value and proved the appearance of self access characteristic among respondents.

\section{Learning Strategies}

Other characteristic mentioned by Dickinson (1993) was the ability to select, use, and monitor learning strategies. This characteristic was found in respondents through their answer to statements "I choose my learning strategies" with 3.5 value, and "I monitor my learning strategies" with 3.6. Other proves were through statements "I try new ways of study and practice" that had 3.6 value, and "I assess and value my learning" with also 3.6 value.

\section{Learning objectives}

According to Dickinson (1993) an autonomous learner should also be able to set his/her learning objectives. This characteristic appeared in respondents answers on statements "I plan how to achieve my goal" that had 4.05 value, and "I choose my content for learning" with 3.7 value. Most respondents knew about the important of learning objective and applied them in their study.

\section{Learning}

\section{Influencing Factors in Autonomous}

It was clear that, based on the answers on questionnaire, the most influencing factor toward autonomous learning of Indonesian students studying in Flinders right now was hometown or place where their previous education conducted. Respondents from Java area, which were considered to have better universities and all the facilities, had better performance on autonomous learning than those from outside of Java. The value of these Java respondents in past experience was 2.9 compared to 2.7 on outside Java respondents. In current activities, the value's difference was greater. Java respondents had 3.9 while outside Java was 3.5. Meanwhile, in belief, the difference was even greater that Java respondents had 4.1 while outside Java only had 3.6.

Actually this data meant a lot as the difference in condition of universities, or even schools, between Java and outside Java covered many things such facilities, teaching staffs, fund and off course the input or students who joined the universities. It could be said then that hometown which influenced by the universities and schools condition was the influencing factor for the existence of autonomous learning in Indonesian Students in Flinders.

\section{CHAPETR V}

\section{Conclusion and Recommendation}

While conducting their study at postgraduate level at Flinders University, Indonesian students must be aware that they must autonomous in learning. The university demands all students in the post-graduate to be able to do self-access and self-manage in conducting their study and to achieve the objective of the study. Since there are differences between the system applied by Flinders and the system run by most Universities in Indonesia, the students in Flinders surely face new thing in their study here regarding the student's autonomy. Some of them especially those who graduated from university outside Java are probably unaware about this system, and it can cause them trouble in conducting study.

Through this study, the awareness of Indonesian students toward autonomous learning is revealed. It is shown from this study that most of Indonesian students at Flinders are already aware of autonomous learning. The awareness toward autonomous learning can be seen through their activities and belief as being students. The degree of autonomy in learning is varied among these students. The data shows that students from Java area have a little bit higher degree of 
autonomy in learning. The cause is probably the standard of most universities in Java which are above universities outside Java such as in Sumatera and Kalimantan.

The limitation in this study is mostly caused by limited number of respondents. There are only twelve respondents involved, and although the separation of group for gender is fairly equal, other groups such as age, hometown, occupation, and current field of study are imbalance. This limitation has made the data obtained becomes insufficient to be calculated and analyzed. This limitation should be overcome by similar study in the future.

Other limitation is in questionnaire. The questionnaire is taken from several studies on autonomous learning in language field. Although the reliability in data collection for language study purpose is good, it turned to be unreliable when applied to this study which covers more general view. Besides, since most of the respondents are in first year studying abroad, it seems that they have difficulties in understanding the statements in questionnaire which are written in formal and unfamiliar English. Future study on this topic is suggested to provide bilingual questionnaire to ease understanding.

\section{REFERENCES}

[1] Ajisuksmo, Clara R. P. and Vermunt, J. D. (1999). Learning styles and self-regulation of learning at university: An Indonesian Study. Asia Pacific Journal of Education, 19(2), 45-59.

[2] Benson, P. (1997). The multiple meanings of autonomy: Responsibility, ability and right. In L. Dickinson (Ed.) Autonomy 2000: The Development of Learning Independence in Language Learning. Bangkok: King Mongkut's Institute of Technology Thornbury.

[3] Benson, P. (2001). Teaching and Researching Autonomy in Language Learning. London: Longman.

[4] Chan, V. (2001). Learning autonomously: The learner's perspectives. Journal of Further and Higher Education, 25(3), 285-300.

[5] Conttia, L. M. W. (2007). The Influence of Learner Motivation on Developing Autonomous Learning in an English-for-SpecificPurposes Course. A dissertation for the Degree of M A in Applied Linguistics at the University of Hong Kong.

[6] Creswell, J. W. (2008). Educational Research: Planning, Conducting, and Evaluating, Quantitative and Qualitative Research (3 ed.). New Jersey: Pearson Prentice Hall.

[7] Dickenson, L. (1995). Autonomy and motivation: A literature review. Systems, 23(2), 165-174.

[8] Faqih, A. (2007). Strategi Peningkatan Mutu Pendidikan. Retrieved $\begin{array}{llll}\text { September } & 4, & & \\ & & \end{array}$ http://abdullahfaqih.multiply.com/journal/item/5

[9] Hasanah, A. (1997). Learning Experiences of Indonesian Postgraduate Students Studying in South Australian Universities, unpublished Master thesis, University of Adelaide.

[10] Ho, J. \& Croocall, D. (1995). Breaking with Chinese cultural traditions: Learner autonomy in English language teaching. Systems, 23(2), 235-243.

[11] Holec, H. (1988). Autonomy and self-directed learning: Present fields of applications. Strasbourg: Council of Europe.
[12] Karsidi, R. (2005). Peningkatan Mutu Pendidikan Melalui Penerapan Teknologi Belajar Jarak Jauh. Retrieved September 4, 2009 from: http:www.uns.ac.id/data/0024.pdf

[13] Lewis, R. (1997). Learning styles in transition: A study of Indonesian students. Paper presented at the annual meeting of the Japan Association of Language Teachers (23rd, Hamamatsu, Japan, October 1997)

[14] Lin, J. (2008). The difference between Western and Eastern education- Education system in need of change? (viewed on August 4th 2009 in http://2008-soph-writingnccu.wikispaces.com/file/view/article+on+educaton).

[15] Little, D. (1991). Learner Autonomy 1: Definitions, Issues and Problems. Dublin: Authentik.

[16] Little, D. (1993). Learning as Dialogue: The dependence of learner autonomy on teacher autonomy. Systems, 23(2), 175-181.

[17] Littlewood, W. (1999). Defining and developing autonomy in East Asian contexts. Applied Linguistics, 20(1), 71-94.

[18] Moser, C and Kalton, G. (1971). Survey Methods in Social Investigation. London: Heinemann Educational.

[19] Murray, D. (2006). Autonomous learning behaviours: A fulcrum for course design, implementation and evaluation with larger classes. Retrieved September 2, 2009 from: www.kansaiu.ac.jp/fl/publication/ pdf_forum/7/07_murray_77.pdf

[20] Novera, I. A. (2004). Indonesian postgraduate students studying in Australia: An examination of their academic, social and cultural experiences. International Education Journal, 5(4), 475-487.

[21] Pennycook, A. (1997). Cultural alternatives and autonomy. In P. Benson \& P. Voller (Eds). Autonomy and Independence in Language Learning. Harlow: Longman.

[22] Ponton, M. K. (1999). The measurement of an adult's intention to exhibit personal initiative in autonomous learning (Doctoral dissertation, George Washington University). Dissertation Abstracts International, 60, 3933

[23] Railton, D. \& Watson, P. (2005). Teaching Autonomy: 'Reading group' and the development of autonomous learning practices. Active Learning in Higher Education, 6(3), 182-193.

[24] Van Lier, L. (1996). Interaction in the Language Curriculum: Awareness, Autonomy, and Authenticity. London: Longman.

[25] Yus, W. S. (2009). 2010, Disdik Fokus Bangun Sains dan Teknologi. $\begin{array}{llll}\text { Retrieved } & \text { September } & 4, & 2009\end{array}$ http://indonesia.go.id/id/index.php?option=com content $\&$ task $=$ view $\&$ id $=9828 \&$ Itemid $=837$ 